\title{
A Clash of Civilizations? Preferences for Religious Political Leaders in 86 Nations
}

NATE BREZNAU

Sociology Department

Bremen International Graduate School of

Social Sciences

JONATHAN KELLEY

International Survey Center
VALERIE LYKES

Department of Psychology

University of Nevada, Reno

M.D.R. Evans

Department of Sociology

University of Nevada, Reno

\section{ABSTRACT}

Huntington claimed that today's major conflicts are most likely to erupt between religiously defined 'civilizations,' in particular between Christianity and Islam. Using World Values Surveys from 86 nations, we examine differences between Christians and Muslims in preferences for religious political leaders. The results suggest a marked difference between Muslims and Christians in attitudes toward religious politicians, with Muslims more favorable by 20 points out of 100. Adjusting for devoutness and education (at the individual level), and degree of government corruption and status as a formerly Communist state (at the national level) accounts for most of the difference. Little support is found for the clash-of-civilizations hypothesis. Instead we find a clash of individual beliefs — between the devout and the secularand enduring differences between the more developed and the less developed world accounts for almost all of the difference between Islam and Christianity with regards to preferences for religious political leaders.

Keywords: Clash of Civilizations, Devoutness, Development, Political Attitudes. 


\section{INTRODUCTION}

Religion continues to influence society and politics. For example, voting in most advanced societies is more closely tied to religion than to socioeconomics (Evans and Kelley 2004; Kelley and Evans 1995); apostates are less likely to be politically conservative and more likely to oppose religion in politics (Hout and Fischer 2002; Hayes 1995; Hayes and McAllister 1995); and religious fundamentalists, taking religion to horrific extremes, fomented recent bombings in New York City, London, and Madrid (Friesen 2007). Religion also shapes foreign policy and cultural conflicts (Green, Rozell, and Wilcox 2001; Haynes 2008; Hunter and Wolfle 2006; Norris and Inglehart 2004; Sherkat and Ellison 1999). Far from fading away, religions are resurgent at the end of the $20^{\text {th }}$ century as seen in the religious revolution in Iran (Habermas 2006), conflict over constitutional Islam in Afghanistan (Olesen 2002), and strong religious voices in right-wing parties in the United States and Western Europe (Norris and Inglehart 2004).

In an influential and much-cited analysis, Huntington (1993:22) stated that future conflict would occur along "cultural fault lines." He asserted that "differences among civilizations are not only real; they are basic. Civilizations are differentiated from each other by history, language, culture, tradition and, most important, religion" (1993:25; emphasis added). Huntington (1993:40) also proposed that the separation of "church and state" (organized religion vs. the government and governmental bureaucracy) is one key issue on which Christian and Muslim 'civilizations' tend to clash. Using World Values Surveys from 86 nations, we examine differences between Christians and Muslims in preferences for religious political leaders.

Views are highly varied over whether political leaders should or should not be religious. The contemporary world splits fairly evenly between those who prefer religious political leaders 
and those who do not, with a substantial portion having mixed or neutral views (Table 1).

Twenty-two percent "strongly agree" and a further 19 percent "agree" that non-believers are unfit for public office (Table 1, panel 1). Some 17 percent have mixed or neutral views; 27 percent "disagree" and another 16 percent "strongly disagree." The mean is near the middle, 51 points out of 100 (scored in equal intervals from 100 for "strongly agree" through 0 for "strongly disagree"). ${ }^{1}$ Similarly, many believe that it would be better for the nation if those with strong religious beliefs held public office (panel 2). Again, opposition approximately balances support: the mean is 52 points out of 100 .

Table 1: Attitudes toward religious political leaders, WVS (1999-2008)

1. Politicians who do not believe in God are unfit for public office.

$\begin{array}{lrr}\text { Strongly agree } & 22 \% & \text { [scored } 100 \text { points] } \\ \text { Agree } & 19 \% & \text { [75 points] } \\ \text { Neither agree nor disagree } & 17 \% & {[50 \text { points] }} \\ \text { Disagree } & 27 \% & {[25 \text { points }]} \\ \text { Strongly disagree } & 16 \% & {[0 \text { points }]} \\ & 100 \% \%^{a} & (144,714 \text { cases }) \\ & & \text { (Mean }=51 \text { points) }\end{array}$

2. It would be better for [Country] if people with strong religious beliefs held public office.

$\begin{array}{lcr}\text { Strongly agree } & 16 \% & {[100 \text { points }]} \\ \text { Agree } & 25 \% & {[75 \text { points }]} \\ \text { Neither agree nor disagree } & 22 \% & {[50 \text { points }]} \\ \text { Disagree } & 24 \% & {[25 \text { points }]} \\ \text { Strongly disagree } & 12 \% & {[0 \text { points }]} \\ & 100 \%{ }^{\mathrm{a}} & (140,937 \text { cases }) \\ & & \text { (Mean }=52 \text { points })\end{array}$

${ }^{\text {a }}$ Percentages may not add up to 100 due to rounding.

${ }^{1}$ This scoring scheme is mathematically equivalent to a conventional Likert equal-interval score for most purposes, but has more intuitive metric of points out of 100 (Evans, Kelley, and Kolosi 1992): 468-469). 
Averaging responses to these two questions, a fairly even balance of preferences appears in many nations, including the United States, India, and Russia. But it is not characteristic of the world as a whole (see Table 2, Appendix S1) ${ }^{2}$. In some countries an overwhelming majority favors religious political leaders (e.g., Georgia, Egypt, Indonesia, and Nigeria with means over 80), while in other countries there is an overwhelming majority against (e.g., Sweden, France, Denmark, and Norway with means at 21 or less). Many, but not all, of the countries in which the public prefers religious political leaders belong to Huntington's Islamic ‘civilization'. By contrast, countries of his Christian, Western 'civilization' are among those least supportive. This finding supports Huntington's clash-of-civilizations hypothesis. Contrary to his views, however, there is also substantial overlap between the two 'civilizations'. To better understand this mixed pattern, we will first discuss the empirical implications of Huntington's hypothesis, next offer some alternative hypotheses, and then proceed to multivariate analyses.

\section{HYPOTHESES}

\section{Clash of Civilizations}

Huntington claims that today's major conflicts erupt between religiously defined 'civilizations', in particular between Christianity and Islam (Huntington 1993: 25). ${ }^{3}$ His hypothesis fits within a broader tradition positing that religious institutions reinforce and promote particular value systems (Friedland 2002; Gill and Keshavarzian 1999:437). Religion

2 Tables 2, 4, 5, and 7 can be found in supplemental Appendix S1, wileyonlinelibrary.com. The technical appendix (Appendix S2) provides syntax to create all tables, thus tables are numbered consecutively, whether or not they are published in the printed journal, to match labels provided in the technical appendix.

${ }^{3}$ A host of facts indicate that the internal differences among Christians and among Muslims in general are erratic (Evans and Kelley 2004; Pfaff and Gill 2006; Starks and Robinson 2009) suggesting that all Christ-based faiths are not uniform in kind or political intents nor are all Islam-based faiths. We follow Huntington's conceptual lead, however, by positing that Muslims and Christians each share similarities on a level that constitutes distinct groups or 'civilizations'. Thus we purposefully group all Muslims on the one hand and all Christians on the other. 
shapes individuals' preferences through socialization, enforcement of doctrine, and by rewarding individuals who personify and enact institutional values and functions (Papadakis and Bean 1993; Pfau-Effinger 2005; Scott 2001). As Huntington (1993) and a plethora of scholars following his thesis points out (see Acevedo 2008), Muslim religious institutions specifically teach their members to venerate religious doctrine as superior to political doctrine. By contrast, Christian institutions induce their members to prefer considerable separation of church and state, a doctrinal development of the past few centuries. The Muslim and Christian nations of the world generally follow these institutional patterns (Fox 2006; Fox and Flores 2009), although Muslim countries vary widely (Lapidus 1996). Thus, the clash of civilizations hypothesis predicts that:

\section{H1: Muslims are more likely to favor religious political leaders than Christians.}

Huntington's hypothesis does not specify a magnitude of difference but clearly implies something larger than the ordinary divisions within nations. Therefore, if this hypothesis holds, the differences between Christians and Muslims should be larger than differences across, for instance, class structure (SES), levels of devoutness, or development levels of nations.

\section{Development (Lack of Corruption, Rule of Law, Prosperity)}

The level of national development may explain differences in support for religious political leaders. The absence of corruption and rule of law are the important elements here. In new or weak democracies, customs and institutional arrangements for carrying out legal principles and minimizing corruption are often absent or ineffectual, so 'clean' government depends more on the personal integrity of governmental officials. In such cases the public prefers political leaders who are personally religious because the public sees these leaders as more likely to have internalized norms and identities that will help them resist the temptation to corruption (Coleman 1990:320). Furthermore, economic resources are scarcer in less developed 
nations so publically desired welfare provisions are increasingly limited (Breznau 2010; Evans, Kelley, and Peoples 2010; Svallfors 2003). Since corruption may divert limited resources, the people of these nations would presumably prefer religious leaders because religion instills strong feelings of charitable duty (Halman and Pettersson 2001). As a country develops and welfare services become institutionalized, the citizenry is likely to expect that their welfare needs will be met via bureaucracies (Gill and Lundsgaarde 2004; Wilensky 1975). However, poorer nationsoften former Western colonies — may reject a secular bureaucratic system as something imposed by the West that failed to provide economic well-being, instead seeing religious systems as a desirable, non-Western alternative (Fox and Sandler 2005). Both scenarios imply that successful economic development will reduce support for religious political leaders.

Thus, in the early stages of a nation's development people will prefer personally devout leaders. As democracy develops, norms and institutional arrangements for minimizing corruption grow in scope and effectiveness, making the personal religious values of public officials less critical for reducing corruption. Yet development includes many features beyond honest government, features such as economic prosperity, political stability, and governmental effectiveness that, unfortunately, are impossible to reliably disentangle and assess (Inglehart and Welzel 2005; Kaufman, Kraay, and Mastruzzi 2008; Morse 2004). Corruption minimization may be the most plausible cause, but these other features could possibly account for or contribute to any development effect we find. Thus:

H2: The more developed a nation is in (a) rule of law and absence of corruption, or (b) strong and effective government, or (c) economic prosperity, the less likely its citizens will prefer religious political leaders. 
Note that this hypothesis is not relevant to the lively, ongoing debate over the traditional secularization thesis that development erodes religious belief (Berger 1999; Inglehart 1990; Kelley 2009; Lechner 1991; Yamane 1997). But it is consistent with a variant of secularization theory that sees institutional specificity, especially separation of church and state, as a key consequence of socioeconomic development (Chaves 1994; Kleiman, Ramsey, and Palazzo 1996), a thesis which helps explain prior findings that citizens of developed nations have an aversion to religious leaders taking political roles (Evans 2001; Norris and Inglehart2002).

\section{Communism}

The explicit, institutionalized materialism of Communist governments led to concerted efforts to extirpate religion (Gautier 1997). To the extent that this government policy left an enduring institutional legacy (Jepperson 1991) or led to effective childhood socialization, it should play an enduring role in preferences:

H3: People living in formerly Communist countries are less likely to prefer religious political leaders.

\section{Socioeconomic and Other Differences}

Differences stemming from education and income may also matter. Modernization theories predict that increased education leads to decreased importance of religion (Berger 1999). Also, religion may provide a sense of security for the poor (Inglehart 2000). These suppositions, which find support in cross-national research (Carlson and Listhaug 2006; Müller 2009), lead to a fourth hypothesis:

H4: People lower in the socioeconomic hierarchy are more likely to prefer religious political leaders. 
Demographic and life-cycle differences in age, marriage, and employment status may matter and the effect may change over time. Although no explicit hypotheses are tested we adjust for these factors in our models.

\section{Individual Devoutness}

Despite Huntington's claims, evidence suggests that denominational differences fail to predict and fully capture religious identity (Alwin et al. 2006) and that individual strength of religious belief, devoutness, is a potent influence on many social phenomena (Smith 2008). Devoutness more than religiosity applies here, because scholars operationalize religiosity in a variety of ways, measuring disparate factors and multiple-latent concepts, sometimes crossing lines of belief and practice (Kelley and de Graaf 1997; Hackney and Sanders 2003). Personal religious devoutness (sometimes labeled belief orthodoxy) is independent of denomination and denomination-based practices, such as attending a church or mosque (Cornwall 1989). Our purpose is to test the possibility that political clashes derive from individual devoutness instead of religious group membership. Those who are more devout are more trusting toward institutions and toward other individuals (Brañas-Garza, Rossi, and Zaclicever 2009; Tan and Vogel 2008; Norenzayan and Shariff 2008). The greatest levels of trust exist between individuals and their leaders when each has a similar level of devoutness; atheists resist religious leaders and the strongest believers welcome them, with moderate believers falling somewhere in between.

H5: More devout individuals are more likely to prefer religious political leaders. 


\section{METHODS}

\section{Data}

Data are from the fourth and fifth waves (2000 and 2005) of the World Values Survey from 86 national surveys where the WVS asked the relevant questions, covering three-fourths of the world's population. The surveys are mostly representative national samples, usually conducted through face-to-face interviews by the local Gallup affiliate (WVS 2010). ${ }^{4}$ After excluding a handful of respondents with missing data, the sample includes: 32,756 Muslims; 37,267 Catholics; 21,493 Protestants; 15,890 Orthodox; 3,847 Buddhists; 2,991 Hindus; 26,110 with 'no' religion; and 6,633 from other faiths in the sample. Most of the analyses are confined to Muslims and Christians, excluding Buddhists, Hindus, those of other faiths, and those with no religion. With these restrictions, there are 107,257 individual cases in the main analysis.

A sensitivity analysis following the methods of Kelley and Evans (2009) indicates that the results are likely representative of the nations of the contemporary world directly sampled in the WVS. A full description of the selectivity analysis conducted for this study is provided in the online technical appendix (Appendix S2, see specifically Tables 7A and 7B) available online at wileyonlinelibrary.com. The results suggest that the WVS oversampled larger nations, more developed nations, formerly Communist nations, and nations with an unequal distribution of income. However, the results reported here are likely not biased by these overrepresentations because we control for development and formerly Communist nations. Furthermore, sensitivity analyses indicated that neither population size nor income inequality are relevant to the issues at hand, so results are not biased by the overrepresentation of larger or more unequal nations.

\footnotetext{
4 The data for the fourth or '2000' wave are from the 4-wave EVS/WVS combined file; and data from the fifth or '2005' wave are from the combined file of the short and long versions of the 2005 WVS; both downloadable at www.worldvaluessurvey.org. See technical appendix for details.
} 
Table 3: Measurement of all variables ${ }^{\mathrm{a}}$

\begin{tabular}{|c|c|c|c|}
\hline Variable & Measurement & Mean & Std. Dev. \\
\hline Religious politicians (DV) & Two-item scale, see Table 1. & 56.2 & 29.2 \\
\hline \multicolumn{4}{|l|}{ Devoutness: } \\
\hline Religious person & $\begin{array}{l}\text { "Independently of whether you go to church or not would } \\
\text { you say you are" (atheist, not religious, religious; scored } \\
0 \text { to } 1 \text { ) }\end{array}$ & 89.1 & 25.1 \\
\hline Prayer / meditation & $\begin{array}{l}\text { "Do you take some moments of prayer, meditation or } \\
\text { contemplation or something like that?" (Dichotomous, } \\
\text { yes=1) }\end{array}$ & 80.9 & 39.3 \\
\hline Importance of religion & $\begin{array}{l}\text { "For each of the following [here religion], indicate how } \\
\text { important it is in your life. Would you say it is:" (4-point } \\
\text { Lickert; scored } 0 \text { to } 1 \text { ) }\end{array}$ & 78.0 & 29.4 \\
\hline Importance of God & $\begin{array}{l}\text { "How important is God in your life? Please use this scale } \\
\text { to indicate" (10-point Lickert; scored } 0 \text { to } 1)\end{array}$ & 82.6 & 26.9 \\
\hline \multicolumn{4}{|l|}{ Denomination ('civilization') } \\
\hline Islamic & $\begin{array}{l}1=\text { Muslim, } 0=\text { Christian, all others excluded from main } \\
\text { analysis }\end{array}$ & .31 & .46 \\
\hline \multicolumn{4}{|l|}{ Demographics/SES: } \\
\hline Male & Male $=1$ & .47 & .50 \\
\hline Age & Years & 41.4 & 16.5 \\
\hline Married & Married=1 & .70 & .46 \\
\hline In labor force & Currently in labor force $=1$ & .60 & .48 \\
\hline Education & Years & 9.44 & 4.82 \\
\hline Income & $\begin{array}{l}\text { Income relative to others in the country } \\
\text { (Index, } 0 \text { to } 100 \text { ) }\end{array}$ & 39.2 & 27.4 \\
\hline Year of survey & (by wave) $1999-2004=0 ; 2005-2008=5$ & 2.04 & 2.46 \\
\hline Formerly Communist & Formerly Communist=1 & .22 & .41 \\
\hline
\end{tabular}


Development: ${ }^{\mathrm{b}}$

Honest government

Strong government

GDP per capita
Mean of 3 measures (each standardized to mean $=1$ and std.dev. $=0$ at the national-level): Rule of law \& corruption; corruption (from Transparency International)

Mean of 4 measures (each standardized): Effective government, stable government, strong regulation, \& democracy

At parity purchasing power per capita in 1998; Index: U.S. $=1.0$
$-.17$

$-.12$

.92

${ }^{a}$ Confined to Muslims and Christians who answered the questions on religious leaders. Data from WVS fourth and fifth waves in 86 nations/societies and 146,987 individuals (107,257 Muslims and Christians) with variation across the measures due to missing data.

${ }^{\mathrm{b}}$ I: World Bank estimates from Kaufman, Kraay, and Mastruzzi 2008, unless otherwise noted; Transparency Iternational data from the Corruption Perceptions Index (2005).

\section{Measurement}

Variable definitions with means and standard deviations are presented in Table 3, further breakdowns by Muslims and Christians can be found in the technical appendix (Table 2A, Appendix S2, wileyonlinelibrary). Socioeconomic and demographic variables are measured using standard conventions.

Dependent Variable: Religious Political Leaders. The measure of preferences for religious political leaders comes from two attitude items (see Table 1). Answers to the two items correlate highly and have very similar correlations with criterion variables (see Table 4, Appendix S1). A principal axis factor analysis shows a clear factor, with both items having factor loadings over $.8($ Cronbach's alpha $=.69)$. A confirmatory factor analysis exhibits an identical result and most of the cross-loading disappears (see Table 3A, Appendix S2). We combine the two measures into a single index coded from 0 to 100 . 
Religious 'Civilizations'. Following Huntington's claim that all Muslims (including Sunni and Shiite) contrast with all Christians (including Catholic, Protestant, and Orthodox), the main analysis excludes those with no religion or those who belong to religions other than Islam or Christianity (roughly 26 percent of the WVS sample). Participation in Muslim 'civilization' is measured by self-definition as a Muslim rather than by citizenship in a Muslim nation.

Sensitivity analysis suggests that Muslims living in Muslim majority nations are not appreciably different from Muslims living in other nations, at least in their preference for religious political leaders. Defining Islamic civilization in terms of individual religious affiliation rather than by nation (or by both individual affiliation and nation jointly) is appropriate.

Devoutness. A four-item scale, calculated as the simple mean of four items (shown in Table 3), measures religious devoutness and is consistent with conventional measures of devoutness (i.e., "religious orthodoxy" in Kelley and de Graaf 1997). Inter-item correlations are satisfactorily high and correlations with select criterion variables appropriately uniform (see Table 4, Appendix S1); values are slightly more impressive considering that three of the items have four or fewer answer categories (Pedhazur 1997:577). Factor analysis shows a clear single factor, with loadings around .7 (Cronbach's alpha $=.76$ ). Scores range from 0 to 100 .

Development. National-level data show that more developed nations tend to have more honest governments (stronger rule of law and less corruption), stronger governments (effective, stable, strong regulation, democratic), and higher GDP. All traits are closely linked, with correlations well over .8 and some above .9 (Table 5, Appendix S1). While there are clear conceptual distinctions separating honest government, strong government, and GDP, differentiating them empirically is not feasible. There are only about 200 nations in the world, but the correlations are so strong that it would take 10 or more times as many to disentangle the 
co-linearity. Honest government is the most crucial aspect of development and is measured as the mean of three components (each standardized to a mean of 0 and standard deviation of 1): a lack of corruption measure from Transparency International (Transparency International 2005) and two from the World Bank (Kaufmann, Kraay, and Mastruzzi 2008).

\section{Analysis}

In a contextual analysis of this kind where national-level data are attached to individuallevel records, the usual standard errors in ordinary least-squares regression are biased downwards (DiPrete and Forristal 1994). We estimate a variance-components multilevel model with random intercepts (e.g., fixed slopes) by country (Hox 1995) using the 'xtreg' routine in Stata 10.

The following equations represent tested models, substituting words for symbols. The first model estimates the maximum effect of Islamic 'civilization' on preferences for religious political leaders. The second model adjusts for demographic characteristics and socioeconomic status. The third model adjusts for devoutness recognizing the possibility of curvilinear effects for religiosity measures (i.e., Nelson and Cantrell 1980) by adding a quadratic term for devoutness and a multiplicative interaction term for Muslim and devoutness. This allows the slope and curvature for Muslims to differ from that for Christians. The final model adjusts for national-level characteristics and change over time. 
CLASH OF CIVILIZATIONS

(Eq. 1) ReligiousPoliticians = Muslim + e1

(Eq. 2) ReligiousPoliticians $=$ Muslim + Male + Age + Married + InLaborForce +

Education + Income $+e 2$

(Eq. 3) ReligiousPoliticians $=$ Muslim + Male + Age + Married + InLaborForce +

Education + Income + Devoutness + DevoutnessSquared + Devoutness $*$ Muslim

+ DevoutnessSquared $*$ Muslim + e3

(Eq. 4) ReligiousPoliticians $=$ Muslim + Male + Age + Married + InLaborForce +

Education + Income + Devoutness + DevoutnessSquared + Devoutness $*$ Muslim

+ DevoutnessSquared $*$ Muslim + HonestGovernment + FormerlyCommunist +

YearOfSurvey + e4

The crucial issue is how much Muslims and Christians differ and how that compares to differences based on devoutness, national characteristics, or SES. For models that are fully linear, calculating such effects is a matter of applying appropriate means to the regression parameters and taking differences in predicted values (Jones and Kelley 1984). But it is not so simple for our preferred model, which contains both curvilinearities and interactions (Eq. 4). We present first differences in predicted values, which are closely related to partial derivatives (King et al. 2004). Predicted values are estimated from an entire population standardization (Kelley and Evans 1995) that makes comparisons using the common reference population of respondents in all 86 nations. The results depend both on the equation and on the population chosen as a baseline for comparison. All cases with missing data on any of the variables are dropped so that each equation applies to an identical population sample.

We estimate Muslim-Christian differences in preferences for religious political leaders as the average of three separate and distinct numbers using Eq. 4 regression coefficients (Table 6): (1) Muslim-Christian differences among the most devout believers; (2) Muslim-Christian 
differences among those with middle levels of devoutness; and (3) Muslim-Christian differences among the least devout believers. Specifically, we predict differences among the strongest believers by changing every case in the sample to the most devout and to Muslim (devoutness=100 and Islamic=1), but leaving all other variables unchanged. Then we compute predicted values for every case. Next we change each case to be Christian (Islamic=0) and again compute predicted values; and finally we average these Muslim-Christian differences across the three levels of devoutness. This technique reveals the most devout Muslims (devoutness=100) are on average 2.4 points (out of 100) more favorable toward religious political leaders than equally devout Christians; the middling in devoutness Muslims (devoutness=75) are 4.1 points more favorable; and lowest believing Muslims (devoutness=50; note that only a few people score lower than this) are 1.5 points more favorable toward religious political leaders than similar Christians. Finally, we summarize Muslim-Christian differences as the average: $(2.4+4.1+$ $1.5) / 3=3$ approximately (see Figure 1 and Figure $2,6^{\text {th }}$ bar).

We obtain the effect of all other variables' first differences in a similar but more straightforward fashion. For example, the effect of honest government comes from comparing predicted values (based on Table 6) for relatively honest governments with scores in the top 10 percent of nations, to those for governments with scale scores in the bottom 10 percent of nations. Comparison points reflect the full range of values, from high (but not extraordinary) to low (but still reasonable). For more details see Appendix S2.

\section{RESULTS}

Results of the preferred multilevel model (Eq. 4) serve as a baseline for the following discussion and figures. The results adjust simultaneously for individual-level and national-level differences. The model explains roughly 30 percent of the variance in the dependent variable. 
Individual devoutness and the national level of corruption (honest government measure) are prominent and statistically significant features (Table 6, rows 2 and 14). In addition, a quadratic term (row 3) shows that the effect of devoutness is curvilinear. 
Table 6: Multilevel model predicting preference for religious political leaders ${ }^{\mathrm{a}}$

\begin{tabular}{|c|c|c|c|c|c|}
\hline row & Variable (see Table 2 for units) & $\begin{array}{l}\text { Metric } \\
\text { effect }\end{array}$ & $\mathrm{SE}$ & $\mathrm{Z}$ & $\begin{array}{c}\text { Std.ized } \\
\text { effect }\end{array}$ \\
\hline & \multicolumn{5}{|l|}{ Individual level variables: } \\
\hline 1. & Islamic (Christian reference) & 5.41 & 1.03 & 5.23 & .09 \\
\hline 2. & Devoutness & .46 & .01 & 87.35 & .36 \\
\hline 3. & Devoutness squared $^{\mathrm{b}}$ & .28 & .01 & 21.26 & .07 \\
\hline 4. & Interaction: Devoutness * Muslim & -.02 & .01 & -1.68 & -.02 \\
\hline 5. & $\begin{array}{l}\text { Interaction: Devoutness squared * } \\
\text { Muslim }\end{array}$ & -.35 & .04 & -9.72 & -.04 \\
\hline 6. & Male & .56 & .15 & 3.79 & .01 \\
\hline 7. & Age & .03 & .01 & 5.66 & .02 \\
\hline 8. & Married & .41 & .17 & 2.33 & .01 \\
\hline 9. & In Labor Force & -.49 & .16 & -3.05 & -.01 \\
\hline 10. & Education & -.44 & .02 & -25.32 & -.07 \\
\hline 11. & Income & -.04 & .00 & -13.47 & -.04 \\
\hline \multirow[t]{2}{*}{12.} & Year of survey & -.25 & .04 & -6.00 & -.02 \\
\hline & \multicolumn{5}{|l|}{ National level variables: } \\
\hline 13. & Formerly Communist & -4.43 & 1.71 & -2.59 & -.15 \\
\hline 14. & Honest government & -8.58 & .77 & -11.21 & -.29 \\
\hline & (Constant) & 19.31 & 1.04 & 18.61 & \\
\hline & Overall $R^{2}$ & .33 & & & \\
\hline & Sigma $u$ & 6.62 & & & \\
\hline & Sigmae & 22.60 & & & \\
\hline & rho (percent of variance due to $u$ ) & .08 & & & \\
\hline
\end{tabular}

${ }^{a}$ Individual $\mathrm{N}=107,257$ Christians and Muslims with complete information on all variables. National N=83; WVS, 1999-2008.

${ }^{b}$ For technical reasons the quadratic term is calculated as ((belief - 75)/100) squared, the 75 is near the center of the distribution, and dividing by 100 makes the coefficients for beliefSq and beliefSq*Muslim easier to interpret. This procedure reduces the danger of rounding error but has no other effect, leading to predictions that, after some algebra, are mathematically identical to those that would be obtained by simple quadratics in the absence of rounding error (see Mosteller and Tukey 1977:285-6). 
Muslims and Christians differ significantly with respect to preferences for religious political leaders (Table 6, row 1), but the interactions in the model (rows 4 and 5) mean that this is not a direct estimate of the size of the differences. That is a more complicated matter, to which we now turn.

\section{Differences between Muslims and Christians}

To begin, if there is a clash of Islamic and Christian 'civilizations', there should be a substantial difference between Muslims and Christians over the separation of church from state. Model 1 estimates the magnitude of that difference (Eq. 1). The result shows that on average, Muslims are 20 points out of 100 more in favor of religious political leaders (Figure 1, $1^{\text {st }}$ bar). 
Figure 1

Support for religious political leaders: Degree to which Muslims are more supportive than Christians. various regression estimates, see Methods section

(Eq. 1) No controls

(Eq. 2) Control SES and demographics

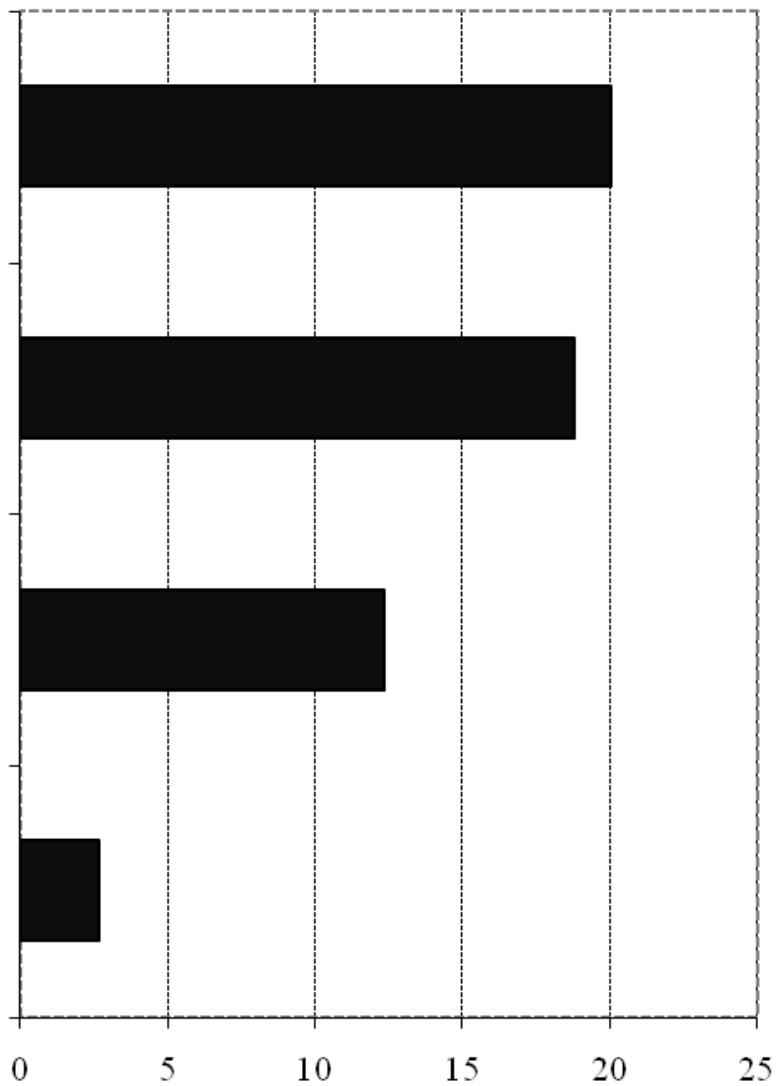

Difference in support: Points out of 100

Although we know of no widely-agreed upon figure established for what magnitude of difference constitutes a clash, we suggest that the term implies at least a gap on the order of 40 points or 50 points out of 100 - a yawning gulf rather than the smaller 20 points we observe. But, for the sake of argument, let us assume that the 20 points does represent a clash of civilizations. Before drawing conclusions we need to purge the gross 20-point difference of various incidentally associated factors that are not part of the religiously defined civilizations per se.

The first set of controls includes the individual-level SES and demographic characteristics (Eq. 2). Taking these characteristics into account shrinks the gap between 
Muslims and Christians to 19 points (Figure $1,2^{\text {nd }}$ bar), only a slight change. The second set of controls adds individual devoutness (Eq. 3) because Muslims are on average noticeably more devout than Christians. When we take devoutness into account, as well as SES and demographic characteristics, the difference between Muslims and Christians over religious political leaders shrinks to 12 points out of 100, around two-thirds of the unadjusted difference (Figure $1,3^{\text {rd }}$ bar).

Finally, Equation 4 also controls for history (by year surveyed and whether the nation surveyed was formerly Communist) and for government corruption. With all of these controls, the difference between Muslims and Christians shrinks to just 3 points out of 100 (Figure $1,4^{\text {th }}$ bar). This is a small, nearly non-existent difference, clearly contrary to the clash-of-civilization predictions of $\mathrm{H} 1$.

\section{Magnitude of the Clash of Civilizations in Perspective}

Figure 2 presents a comparison that puts the Muslim-Christian 3-point difference into perspective. The bars in Figure 2 represent a comparison of the first difference in support for religious politicians between the extremes of given indicators, for example between the strong believers and the doubters within the two religions, or between the other individual- and national-level variables. The most important is individual devoutness. Highly devout Christians (devoutness=100) compared to more secular Christians (devoutness=40) are 27 points out of 100 more favorable towards religious politicians, all else being equal ( $1^{\text {st }}$ bar $)$. Significantly, for Muslims there is a comparable result of 26 points, nearly the same gap between the most devout (100) and a comparably lower level (40) of devoutness (Figure 2, $2^{\text {nd }}$ bar). These large differences of nearly 30 points are within 'civilizations', dwarfing the across 'civilization' Muslim-Christian effect of a mere 3 points (reproduced here as the $6^{\text {th }}$ bar of Figure 2 ). These are almost 10 times (or 1,000 percent) larger in magnitude. 
Figure 2

Support for religious political leaders; First differences estimated by multilevel regression, see Table 6

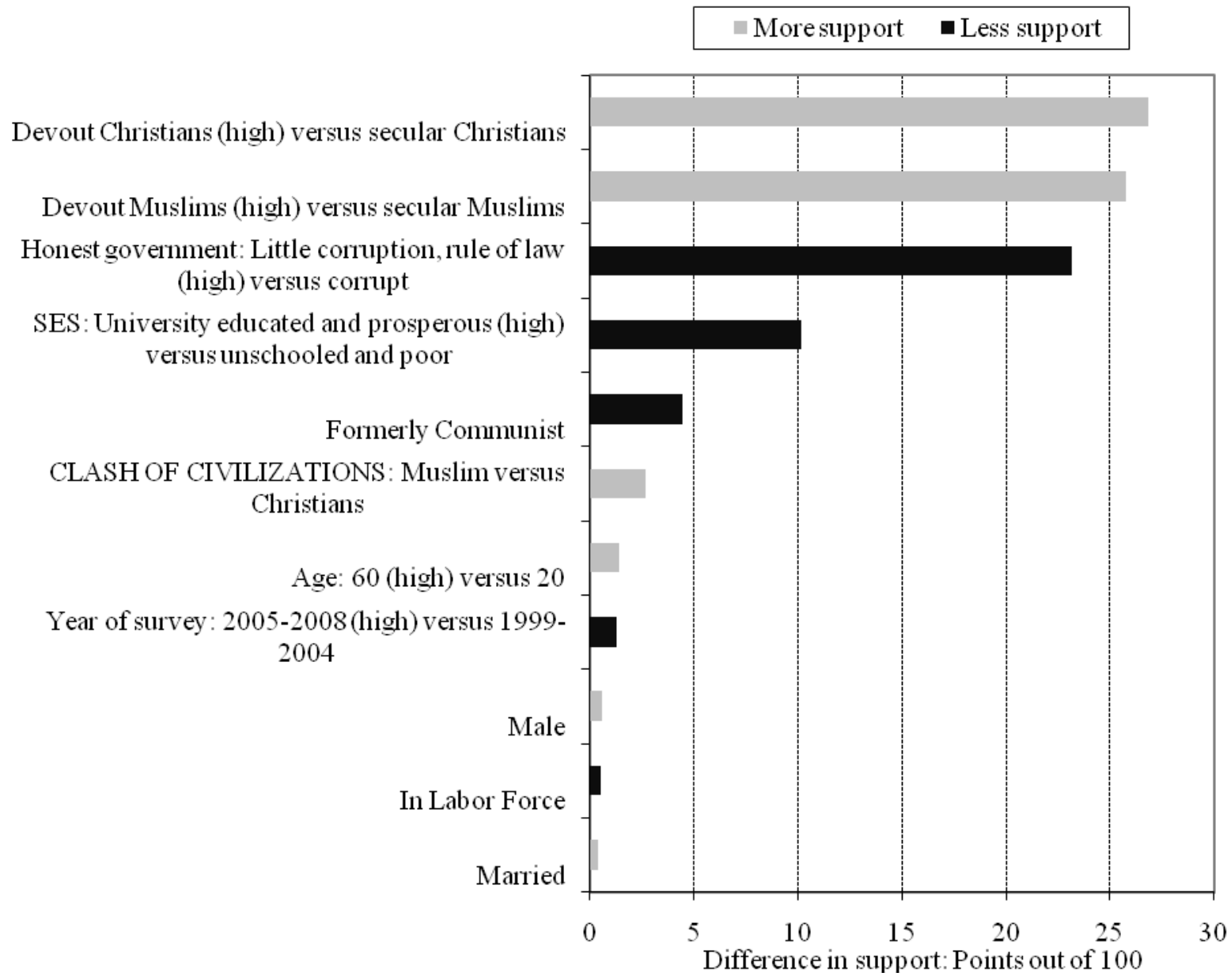

The next most potent influence is honest government (Figure 2, $3^{\text {rd }}$ bar). Citizens of countries where the rule of law is securely entrenched and where corruption is minimal are over 20 points out of 100 less supportive of religious political leaders compared to their peers in countries where law lacks power and corruption is rife. ${ }^{5}$

\footnotetext{
5 The comparison here is between countries in the most honest, law bound 10 percent of nations (including Denmark, Sweden, Australia, and the Netherlands) and the most corrupt, least law bound 10 percent of nations (including Bangladesh, Nigeria, Indonesia, and Iraq). Of course the most honest governments are generally also the strongest and in the richest nations, and the least honest are generally weak, poor, and undemocratic (see Table 4, Appendix S1).
} 
Socioeconomic differences are also important, although not as important as differences in devoutness or between honest and corrupt governments $\left(4^{\text {th }}\right.$ bar). University-educated and highincome individuals are about 10 points out of 100 less supportive of religious political leaders than are those lacking schooling and low in the income hierarchy. ${ }^{6}$ This contrast is about onethird the size of the effect of devoutness and about half that of honest government. The legacy of Communism accounts for the next largest effect $\left(5^{\text {th }}\right.$ bar $)$, with people living in formerly Communist countries 4 points out of 100 less supportive of religious political leaders than otherwise similar citizens of countries where Communism never held sway.

The clash of civilizations trails all these in importance, a difference of just under 3 points out of $100\left(6^{\text {th }}\right.$ bar $)$. This is about one-tenth the size of the net effect of devoutness. It is also dramatically smaller than the effect of honest government, much less important than SES variables, and scarcely more than half the size of Communism's modest anti-religious legacy. The average person was about 1.2 points out of 100 less favorable towards religious politicians in 2005 than they were just five years previously ( $7^{\text {th }}$ bar). Thus the Muslim-Christian clash-ofcivilizations effect (H1) is only 1.4 points larger than the effect of just five years of history. ${ }^{7}$ Finally, there are tiny demographic differences of less than 1 point for gender, labor force participation, and marital status (last 3 bars).

\footnotetext{
${ }^{6}$ Specifically, the comparison is between those with university education (roughly the top 10 percent in the WVS sample) and incomes in the top decile, who rate leaders 47; and those with no education (the bottom 3 percent) and income in the lowest decile, who rate religious political leaders 56 points out of 100 . The difference between these two, $47-56=-9$ points is a (generous) estimate of the SES effect.

${ }^{7}$ Note that we estimate a separate model for capturing the effect of time including only the countries surveyed in both waves to test for a genuine time-effect, as some countries were surveyed either in 2000 or 2005. Results are nearly identical (see Appendix S2).
} 


\section{Religious Denomination and Devoutness: A Closer Look}

While devoutness is the dominant predictor of support for religious political leaders, several important differences between Muslims and Christians play a part in the way this comes about. The salient differences are not easy to see by visual inspection of the regression coefficients in Table 6 because the model (Eq. 4) includes quadratic terms and interaction terms. To show the patterns clearly, we present confidence bands around separate regression lines for Muslims (solid lines in Figure 3) and Christians (broken lines in Figure 3). For each level of individual devoutness, there is a 95 percent confidence interval for the associated mean level of support for religious political leaders, all else equal. Plotting these confidence intervals across the whole spectrum of devoutness gives the confidence bands. We are 95 percent certain that the true worldwide average levels of support for religious political leaders lie between the corresponding lines. 
Figure 3

Clash of civilizations? Belief and preference for religious politicians: $95 \%$ confidence intervals

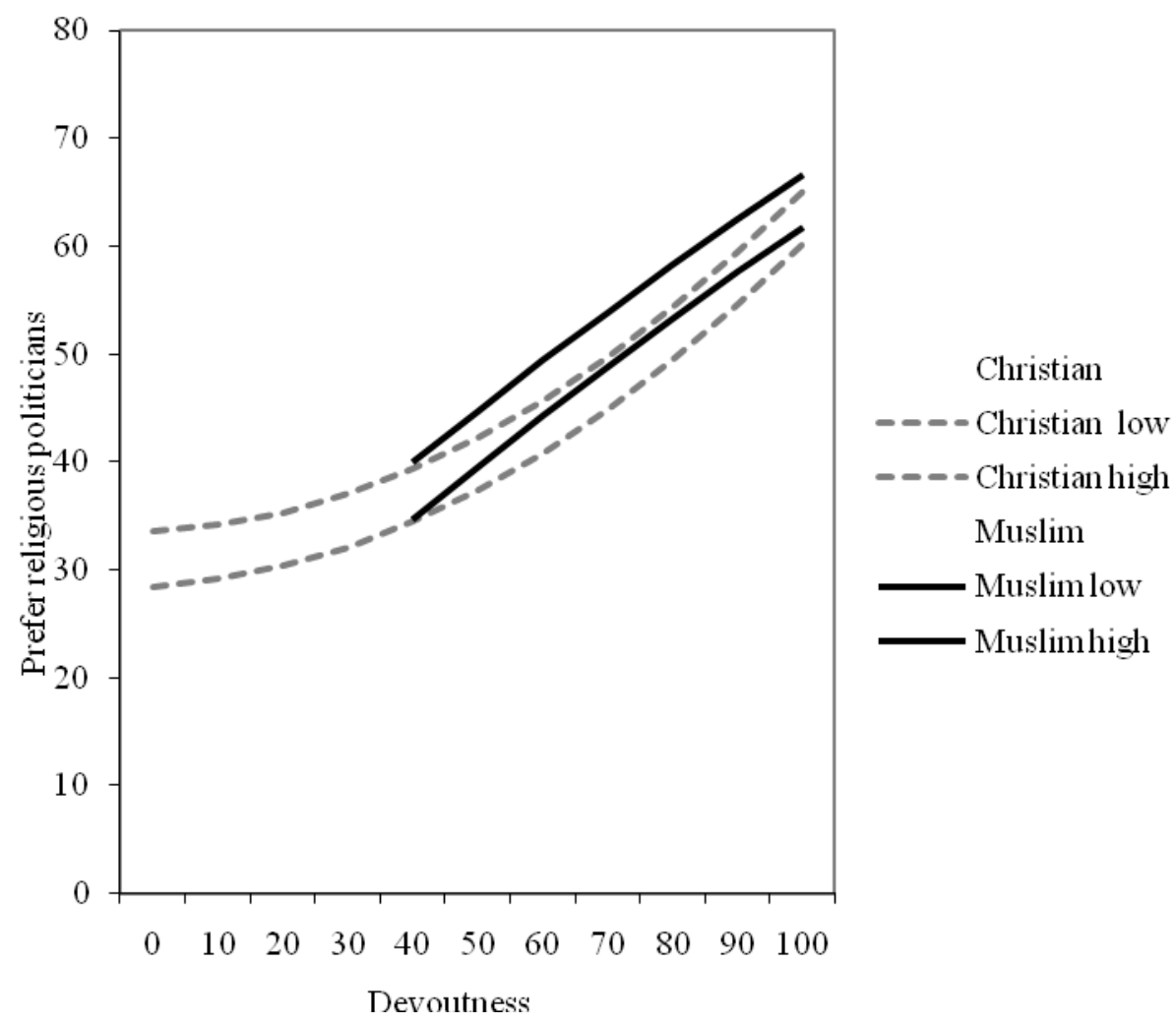

What would the bands show if there was a clash of civilizations? Both would have a positive slope, although probably not a steep one (since the value would be widely diffused within the civilization), and they would be distinct, with the confidence band for Muslims substantially higher than the confidence band for Christians, consistent with the clash-of-civilizations hypothesis $(\mathrm{H} 1)$.

Among nominal Christians (dashed lines in Figure 3; devoutness=0), the true mean level of support for devout political leaders is between 28 and 33 points out of 100, all else equal. Support increases with devoutness, so that for people of middling devoutness (devoutness $=50$ ), 
we are confident that the true mean level of support lies between 37 and 42 . Then the curve steepens, so that among the most devout Christians (devoutness=100), the true level of support for devout political leaders lies between 60 and 65 points. This figure indicates a very substantial positive effect.

Turning to the Muslims the solid lines in Figure 3 show levels of devoutness above 40 because almost all Muslims (95 percent) are at or above this level of devoutness. Nowhere is there much of a gap between the confidence bands for Muslims and Christians, indicating substantial similarity of the effect of devoutness in the two groups. Indeed, for relatively secular folk with levels of devoutness around 40 , there is no statistically clear difference between Muslims and Christians because the confidence bands overlap. This is also true among the strongest believers with devoutness around 100. Muslims and Christians are somewhat further apart at medium-high levels where devoutness is about 70, but even here the confidence bands still overlap. These results are not consistent with the clash-of-civilizations hypothesis (H1). The two groups cannot be reliably distinguished across most of the range of religiosity, and nowhere is there a substantial gap between them.

\section{Another Angle on Civilizations: The Religious Majority}

In Muslim-majority nations, political leaders will almost always be Muslim, not Christian, and vice-versa in Christian-majority nations. For Muslims in Muslim-majority nations the question about religious leaders suggests "leaders of your faith," but for Christians in those Muslim nations the question reads "leaders of a different faith than yours" and vice-versa in Christian-majority nations. We assumed thus far that the relationship between devoutness and preferences for religious political leaders is unaffected by the most likely faith of religious leaders in that country. Perhaps differences in national context matter, as they do for some other 
aspects of religious culture (Kelley and de Graaf 1997; Stark and Bainbridge 1987). In particular, perhaps devout people support religious politicians due to homophily (McPherson, Smith-Lovin, and Cook 2001), in this case preferring politicians of one's own religion. Or support might be out of self-interest (Marx 1927), since there may be material gains if co-religionists are in power.

If either homophily or self-interest held sway, the strong positive effect of devoutness on support for religious politicians would only be a force among members of the dominant religion in a nation. By looking at the effect of devoutness among Christians in Muslim-majority nations and among Muslims in Christian-majority nations, it is possible to test for this. Results show that the devoutness effect is very strong (and in the same direction) in both religions regardless of which religion is dominant (Figure 4; see also Table 7 below, panel 5). For Muslims in majority Muslim nations, the gap in support between the weakest believers and the strongest believers is about 27 points out of 100 (Figure 4). Christians living in Muslim-majority nations are also keen on religious political leaders, with a similar increase of 26 points between weak and strong believers, and the predicted values (top two lines in Figure 4) are similar in magnitude and trajectory. Thus Christians in Muslim-majority countries display attitudes almost identical with Muslims in these countries. We find no sign of homophily or self-interest. 
Figure 4

Preferences for religious political leaders in Muslim majority nations and in other nations: Predicted values from multilevel model controling other things

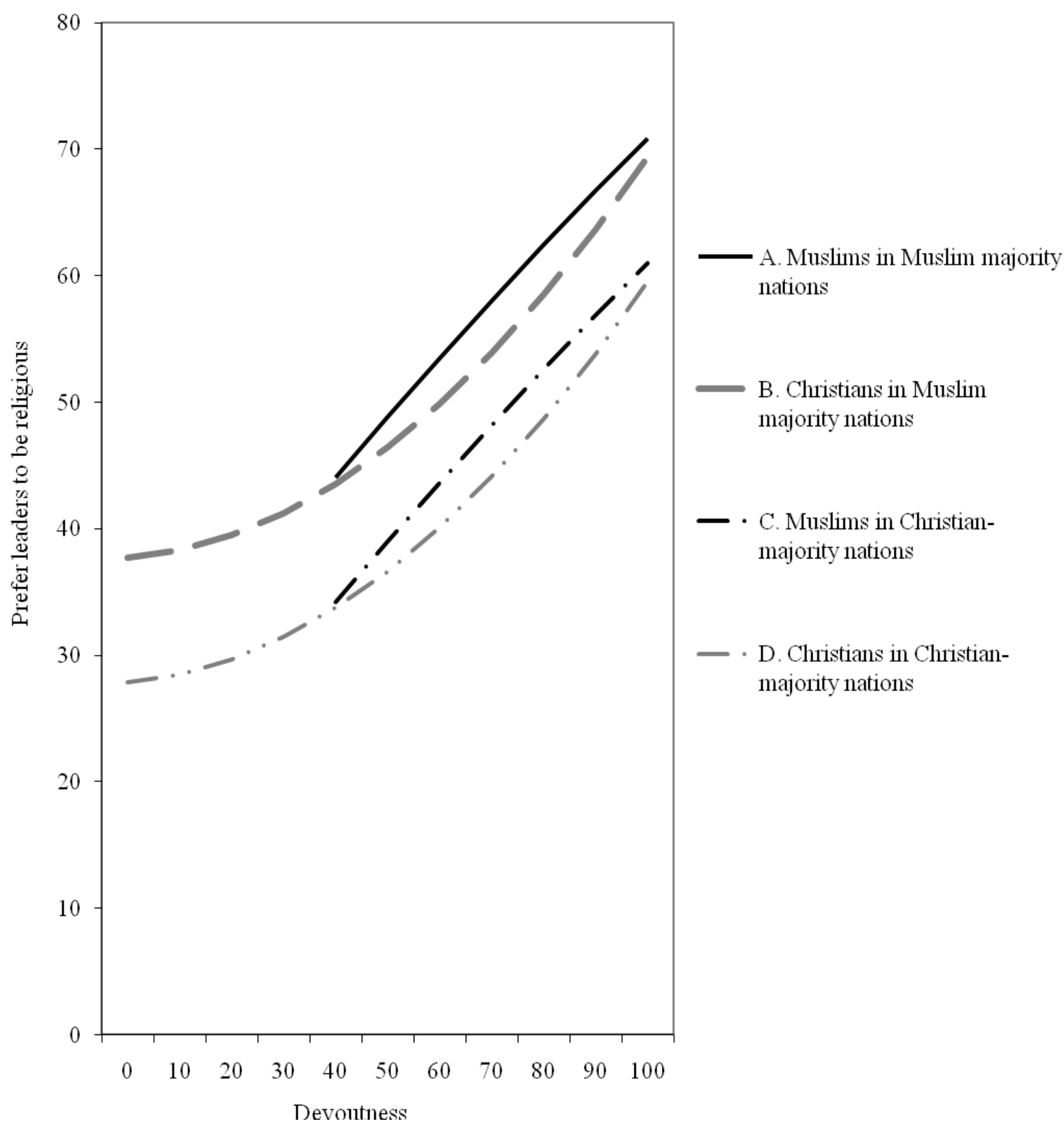

In Christian nations, the results for Muslims and Christians are nearly indistinguishable: Support for religious politicians increases with devoutness for both Muslims and Christians, again refuting homophily and self-interest as factors (bottom two lines of Figure 4). The 
impulses toward homophily and self-interest may have a role in religious life, but not here. This further contradicts the idea of a clash between religiously defined civilizations (H1).

\section{Sensitivity Analyses}

The model described above (Eq. 4) seems to perform well, but we considered several alternatives to be sure. We engage in sensitivity analyses to systematically assess the key findings under a variety of specifications and with the inclusion of various additional variables. Results are summarized in Table 7, Appendix S1.

Uneven cross-sections. In the WVS, not all countries were surveyed in both the fourth and fifth waves. Statistically it is possible that results are biased by which countries are in the respective cross-sections. Therefore, we ran the analysis on only those countries surveyed in both waves (26 countries and 51 thousand individuals). Results are nearly identical suggesting that the main findings are unbiased by country selectivity in the different waves.

Other Denominations. Aside from Huntington's prediction of a clash between Islamic and Christian civilizations, how the Islamic religion might contrast with other religions is unclear. The sensitivity analysis shows that Protestants are fractionally more supportive of devout political leaders than are Muslims; Orthodox Christians and Muslims hold views that are not significantly different; Catholics are a bit less supportive; and Hindus, Buddhists, and those claiming "no religion" less supportive. None of these differences is large, certainly not large enough to constitute a clash of civilizations. The greatest difference is between Hindus and those of "no religion" compared with Muslims. Thus, we find no evidence of civilization clashes across any of the major world religions. ${ }^{8}$

\footnotetext{
${ }^{8}$ Huntington discusses the prominent role of Judaism in global conflicts; however, we cannot account for cross-national differences among Jews or compare them with other religions since there were 20 or fewer individuals (often none) surveyed in countries other than Israel.
} 
Alternatives to Development. In our preferred model, we use an honest government scale as the key national development characteristic. Nonetheless, as previously noted (Table 5), diverse aspects of development are so strongly correlated empirically, that it is possible the interpretation is incorrect. When honest government is left out of the equation and GDP and a World Bank measure of governmental strength and effectiveness (Kaufmann, Kraay, and Mastruzzi 2008) are included one at a time, the results show that these substitutions leave the other results essentially unchanged. Especially significant, the difference between Muslims and Christians and also the contrast between nominal and devout Muslims are both unaffected by the substitutions. Although we prefer the honest government measure on theoretical grounds, any of the three measures empirically gives the same result. (This substitutability of conceptually dissimilar measures has uncomfortable implications for scholars who work with national-level measures of GDP, development, and corruption.)

Splitting up the Dependent Variable. Results of the factor analyses justified combining the two indicators of support for religious political leaders into one index, and this is ultimately preferable because combining them reduces random measurement error and improves measurement of the latent concept of support for religious political leaders. Nonetheless, it remains possible that effects relevant to the clash-of-civilizations hypothesis could differ between the two. Accordingly, we re-estimated the baseline model separately for each of the two variables measuring attitudes toward religious politicians. Results show that splitting up the dependent variable introduces more random noise, but otherwise does not alter the very small size of the Muslim-Christian contrast, nor the very large size of the contrast between least and most devout Muslims. 
The National Religious Context. As discussed previously (Figure 4), it could be that the people living in majority Muslim nations have views about the need for religious political leaders shaped by the religious identity of their nation rather than their own affiliations and devoutness. Three sensitivity analyses explore this possibility. First, we augmented the baseline model with a dummy variable indicating whether or not the respondent lived in a majority Muslim country. Second, we added a measure of the average level of devoutness in the nation. Third, we consider both together. In all cases, the key effects are unchanged. The R-squared does not change significantly and the other important differences remain similar to the baseline model.

Religious Context. Perhaps support for religious political leaders is merely an artifact of the institutionalization of relationships between church and state through the promulgation of religious laws. Fox's valuable international comparative project on the level of church and state integration provides measures of the extent of religious laws and of whether there is a state religion for most of countries in the WVS (Fox 2004). First, we add a measure of the extent of religion in law, and it does not change the very small size of the Muslim versus Christian contrast, or the very large size of the between nominal and devout Muslims. Second, including both the extent of religion in law and the existence of an established state religion also leaves the key effects unchanged.

Democracy. We augment the baseline model with a measure of how democratic each country is (Table 7, Appendix S1). The democracy effect is not significant and again the key results from the baseline model do not change.

Educational Context. In case national modernization shapes attitudes rather than individual education, we augment the baseline model with a measure of the average educational attainment in the nation. The effect is barely significant and leaves the key results from the 
baseline model intact. This might be an interesting avenue for future research as educational context appears to produce a slight increase in support for religious political leaders despite their small negative correlation. The fact that this model controls for individual education and honest government, both moderately correlated with educational context, might blur the results for educational context. For our present analysis, this possibility is not important. The addition of average education of a nation does not change the main findings.

Sample Selectivity. The WVS sample of countries is not random. In addition to the development variables already discussed, WVS countries tend to have larger populations and more unequal nations (Tables 7A and 7B, Appendix S2). We thus use these two variables as controls to further test robustness. Augmenting the baseline model in this way neither of these new variables is statistically significant and the key results remain unchanged. In sum, the results given in the baseline model are robust to a wide array of model augmentations and respecifications.

\section{DISCUSSION}

Great diversity appears among nations in the degree to which their citizens favor religious political leaders, although Muslim-majority nations are the most supportive. Christianmajority nations, despite more variation, are generally much less supportive (Table 2, Appendix S1). Does this reflect a clash of civilizations as proposed by Huntington (1993) and operationalized in our first hypothesis? We bring a variety of analyses and evidence to bear on this question and univocally conclude that this hypothesis ought to be rejected. At the descriptive level, we initially note a great deal of diversity among Christian nations, considerable diversity among Muslim nations, and a fair bit of overlap between them. More systematic analysis reveals, however, that the significant unadjusted difference of 20 points out of 100 (Figure 1) between 
individual Muslims and Christians in their preference for religious political leaders is mostly an artifact of differences in individual levels of devoutness and in national levels of corruption. Using multilevel regression analyses to control for social composition, devoutness, and national characteristics, the independent effect of denomination alone is very small, about 3 points out of 100. Moreover, in the brief window of time captured by the WVS at the beginning of the first decade of the new millennium, the effect is already declining and may by now have disappeared entirely. Furthermore, the difference between devout Muslims and secular Muslims is far greater than the difference between Muslims and Christians (Figure 2). What we are seeing is a variant of secularization, an old and familiar story, not a clash of 'civilizations'. There may be a small jangle (rather than clash) of civilizations here, but not more.

Our analysis improves on Norris and Inglehart's (2002, Table 4). They estimated a somewhat similar model using earlier WVS data (from 1995 through 2001) and obtained a Muslim-Christian difference of 9 points, thrice the size of ours. This disparity appears to arise because their model neglects curvilinearity in the effect of devoutness, neglects the MuslimChristian differences in the way devoutness impacts preferences, and uses weaker measures of societal development. But even their 9-point difference is not large enough to signal a clash of civilizations. These findings provide evidence that the likelihood for any potential clash is in decline. The model we employ also improves on Norris and Inglehart's by accounting for the non-linear nature of the impact of devoutness and utilizing a larger sample of nations with more recent data.

In investigating a clash of civilizations, at least three alternative hypotheses come to the fore to explain the differences between Muslim and Christians. The first is that national development is a major influence on support for religious political leaders (H2). The results of 
our multi-level analysis are consistent with this supposition and the effect is also very large (Table 6). We must attach a caveat, however, in that the correlations among different aspects of development are so high that there is no strong empirical basis for preferring one over the other. We interpret the strong effect of honest government (e.g., rule of law and corruption minimization) in decreasing support for religious political leaders as indicating that the citizenry views a leader's personal religious piety as a signal of integrity and compassion; hence the desire for religious political leaders fades as structure replaces character as the main guarantor of 'good' government. Yet, the same empirical pattern holds using other indicators of development such as GDP (Table 7, panel 3, Appendix S1). Our interpretation emphasizing the honesty of government is strengthened by the analogue of a recent finding that people in undeveloped countries prefer to use the pay system rather than the government to achieve redistribution, whereas their peers in advanced countries prefer government mechanisms (Evans, Kelley, and Peoples 2010).

Second, the prolonged governmental antagonism to organized religion in the Soviet empire (Gautier 1997) left a legacy of reduced support for devout politicians (H3). The results support this hypothesis, showing a small but significant effect. The effect amounts to 6 points out of 100 , or twice the size of the effect of membership in the Islamic 'civilization'. Given that this result is net of individual devoutness and other controls, Communism has had a small but real and enduring impact on individual political attitudes as observed in other domains (Breznau 2010; Kelley and Evans 2009).

Third, increased education and income lead to less support of religious political leaders (H4). Taken altogether, the SES effects are larger than the difference between members of Muslim and Christian 'civilizations' and also larger than the differences between nations with 
and without a Communist legacy. If we were to define the relatively smaller gap between Muslims and Christians as a clash of civilizations, to keep things in proportion we would need to label the SES effects "class warfare," clearly a gross exaggeration. Instead we simply note the relevance of modernization theory and the functional security that religion provides to those lower in income.

The most powerful finding explaining Muslim and Christian differences derives from the investigation of individual devoutness (H5). This is by far the largest, indeed the dominant, effect in the model. Moreover, the political correlation with devoutness is probably not a communal attempt to garner advantage for any particular religious group since the pattern of preference for religious political leaders holds true not only for people who belong to the religious majority, but also for religious minorities, thus ruling out homophily and self-interest (Table 7, panel 2, Appendix S1). There may be a clash of devoutness brewing, but this is not a characteristic of any civilization, or indeed of any single nation.

In sum, we find no support for the clash of civilizations hypothesis in patterns of preference for religious political leaders. In fact, the evidence argues for the rejection of Huntington's evocative thesis, one of the more controversial and disputed claims in the realm of international politics (Henderson and Tucker 2001; Russett, O'Neal, and Cox 2000). The analysis indicates that Muslim-Christian differences do play a role, but it is a tiny one, and declining over time. Although the clash-of-civilizations hypothesis cannot be rejected categorically, the scope can be restricted dramatically. A full test will ultimately require similar analyses of attitudes on other aspects of the separation of church and state, and especially other topics highlighted by Huntington in his thesis, such as history (beyond recent history and former Communist rule), language and symbols, and attitudes toward war, most specifically 'holy' wars. 
Furthermore, the findings do not guarantee that violence in the name of religion will decline globally. In fact devoutness alone may be a source of national violence, independent of religious denomination (Ellingsen 2005). Thus, if repeated testing shows that political attitudes do not differ across Muslims and Christians as separate 'civilizations', further scholarship should also attempt to account for divergent types of devoutness that occur across groups and individuals within the umbrella categories of Muslim and Christian, a divergence that might aptly be labeled a 'clash of devoutness'. Finally these findings should inform further scholarship on the importance of individual devoutness, religious-political attitudes, post-Communism, corruption, and national development. 


\section{REFERENCES}

Acevedo, Gabriel A. 2008. Islamic fatalism and the clash of civilizations. Social Forces 86(4):1711-52.

Alwin, Duane F., Jacob L. Felson, Edward T. Walker, and Paula A. Tufişs. 2006. Measuring religious identities in surveys. Public Opinion Quarterly 70(4):530-64.

Berger, Peter L, ed. 1999. The desecularization of the world: Resurgent religion and world politics. Grand Rapids, MI: W. B. Eerdmans.

Brañas-Garza, Pablo, Máximo Rossi, and Dayna Zaclicever, 2009. Individual's religiosity enhances trust: Latin American evidence for the puzzle. Journal of Money, Credit and Banking 41(2-3):555-66.

Breznau, Nate. 2010. Economic equality and social welfare: Policy preferences in five nations. International Journal of Public Opinion Research 22(4):458-84.

Carlson, Matthew and Ola Listhaug. 2006. Public opinion on the role of religion in political leadership: A multi-level analysis of 63 countries. Japanese Journal of Political Science 7(3):251-71.

Chaves, Mark. 1994. Secularization as declining religious authority. Social Forces 72(3):749-74.

Coleman, James. 1990. Foundations of social theory. Cambridge, MA: Harvard University Press

Cornwall, Marie. 1989. The determinants of religious behavior: A theoretical model and empirical test. Social Forces 68(2):572-92.

Transparency International. 2005. Corruption Perceptions Index. Accessed online October 2010. Available at: http://www.transparency.org

DiPrete, Thomas A. and Jerry D. Forristal. 1994. Multilevel models: Methods and substance. Annual Review of Sociology 20(1):331-57.

Ellingsen, Tanja. 2005. Toward a revival of religion and religious clashes? Terrorism and Political Violence 17(3):305-32.

Evans, M.D.R. 2001. Should clerics refrain from politics? Australians' ideals, with international comparisons. Australian Social Monitor 4(1):1-8.

Evans, M.D.R. and Jonathan Kelley. 2004. Religion and Politics in 28 Nations. In Australian economy and society 2002: Religion, morality, and public policy in international perspective, 1984-2002, edited by M.D.R. Evans and Jonathan Kelley, pp. 95-112. Sydney, Australia: The Federation Press.

Evans, M.D.R., Jonathan Kelley, and Tamas Kolosi. 1992. Images of class: Public perceptions in Hungary and Australia. American Sociological Review 57(4):461-82.

Evans, M.D.R., Jonathan Kelley, and Clayton Peoples. 2010. Justifications of inequality: The moral basis of pay differentials in 31 nations. Social Science Quarterly 91(5):1405-31.

Fox, Jonathan. 2004. Religion and state dataset. The religion and state project. Available at: http://www.thearda.com/ras/downloads/ . 2006. World separation of religion and state into the 21 st century. Comparative Political Studies 39(5):537-69

Fox, Jonathan and Deborah Flores. 2009. Religions, constitutions, and the state: A cross-national study. The Journal of Politics 71(4):1499-1513. 
Fox, Jonathan and Shmuel Sandler. 2005. Separation of religion and state in the twenty-first century: Comparing the Middle East and western democracies. Comparative Politics $37(3): 317-35$

Friedland, Roger. 2002. Money, sex, and god: The erotic logic of religious nationalism. Sociological Theory 20(3):381-425.

Friesen, Katie. 2007. The effects of the Madrid and London subway bombings on Europe's view of terrorism. Human Rights and Human Welfare 7(Supplementary):S10-S17.

Gauchet, Marcel. 1997. The disenchantment of the world: A political history of religion. Princeton, NJ: Princeton University Press.

Gautier, Mary L. 1997. Church attendance and religious belief in postcommunist societies. Journal for the Scientific Study of Religion 36(2):289-96.

Gill, Anthony and Arang Keshavarzian. 1999. State building and religious resources: An institutional theory of church-state relations in Iran and Mexico. Politics and Society 27(3):431-65.

Gill, Anthony and Erik Lundsgaarde. 2004. State welfare spending and religiosity: A crossnational analysis. Rationality and Society 16(4):399-436.

Green, John C., Mark J. Rozell, and Clyde Wilcox. 2001. Social movements and party politics: The case of the Christian Right. Journal for the Scientific Study of Religion 40(3):413-26.

Habermas, Jürgen. 2006. Religion in the public sphere. European Journal of Philosophy 14(1):125.

Hackney, Charles H. and Glenn S. Sanders. 2003. Religiosity and mental health: A meta-analysis of recent studies. Journal for the Scientific Study of Religion 42(1):43-55.

Halman, Loek and Thorleif Pettersson. 2001. Religion and social capital: results from the 1999/2000 European Values Study. Research in the Social Scientific Study of Religion 5(1):65-90.

Hayes, Bernadette C. 1995. The impact of religious identification on political attitudes: An international comparison. Sociology of Religion 56(2):177-94.

Hayes, Bernadette C. and Ian McAllister. 1995. Religious independents in Northern Ireland: Origins, attitudes, and significance. Review of Religious Research 37(1):65-83.

Haynes, Jeffrey. 2008. Religion and foreign policy making in the USA, India and Iran: Towards a research agenda. Third World Quarterly 29(1):143-65.

Henderson, Errol A. and Richard Tucker. 2001. Clear and present strangers: The clash of civilizations and international conflict. International Studies Quarterly 45(2):317-38

Hout, Michael and Claude S. Fischer. 2002. Why more Americans have no religious preference: Politics and generations. American Sociological Review 67(2):165-90

Hox, Joop J. 1995. Applied multilevel analysis. Amsterdam, Netherlands: TT-Publikaties.

Hunter, James Davison and Alan Wolfle. 2006. Is There a Culture War? A Dialogue on Values and American Public Life. Washington, D.C.: Brookings Institution Press.

Huntington, Samuel P. 1993. The clash of civilizations? Foreign Affairs 72(3):22-49.

Inglehart, Ronald. 1990. Culture shift in advanced industrial society. Princeton, NJ: Princeton University Press. . 2000. Globalization and postmodern values. Washington Quarterly 23(1):215-28 
Inglehart, Ronald and Christian Welzel. 2005. Modernization, cultural change and democracy: The human development sequence. Cambridge, UK: Cambridge University Press.

Jepperson, Ronald. 1991. Institutions, institutional effects, and institutionalism. In The new institutionalism in organizational analysis, edited by Walter W. Powell and Paul J. DiMaggio, pp. 143-63. Chicago, IL: University of Chicago Press.

Jones, Frank L. and Jonathan Kelley. 1984. Decomposing differences between groups: A cautionary note on measuring discrimination. Sociological Methods and Research 12(3):323-43.

Kaufmann, Daniel, Aart Kraay, and Massimo Mastruzzi. 2008. Governance matters VII: Aggregate and individual governance indicators 1996-2007. The World Bank Policy Research Working Paper 4654.

Kelley, Jonathan. 2009. Review of The Role of Religion in Modern Societies, edited by Detlef Pollack and Daniel V. A. Olson. American Journal of Sociology 114(6):1874-6

Kelley, Jonathan and Nan Dirk de Graaf. 1997. National context, parental socialization, and religious belief: Results from 15 nations. American Sociological Review 62(4):639-59.

Kelley, Jonathan and M.D.R Evans. 1995. Class and class conflict in six western nations. American Sociological Review 60(2):157-78. .2009. Economic development reduces tolerance for inequality: A comparative analysis of 30 nations. In Charting the Globe: The International Social Survey Programme 19842009, edited by Max Haller, Roger Jowell, and Tom Smith, pp. 49-72. London, UK: Routledge.

King, Gary, Christopher J. L. Murray, Joshua A. Salomon, and Ajay Tandon. 2004. Enhancing the validity and cross-cultural comparability of measurement in survey research. American Political Science Review 98(1):191-207.

Kleiman, Michael B., Nancy Ramsey, and Lorella Palazzo. 1996. Public confidence in religious leaders: A perspective from secularization theory. Review of Religious Research 38(1):79-87.

Lapidus, Ira M. 1996. State and religion in Islamic societies. Past and Present 151(1):3-27.

Lechner, Frank J. 1991. The case against secularization: A rebuttal. Social Forces 69(4):110319.

Marx, K. 1927. Capital: A Critique of Political Economy, $3^{\text {rd }}$ ed. Edited by Friedrich Engels and Samuel Moore; translated by Edward Aveling. Chicago, IL: Charles H. Kerr and Company.

McPherson, Miller, Lynn Smith-Lovin, and James M. Cook. 2001. Birds of a feather: Homophily in social networks. Annual Review of Sociology 27(1):415-44.

Morse, Stephen. 2004. Indices and indicators in development: An unhealthy obsession with numbers. Sterling, VA: Cromwell Press Limited.

Mosteller, Frederick and John W. Tukey. 1977. Data Analysis and Regression. Reading MA: Addison-Wesley.

Müller, Tim. 2009. Religiosity and attitudes towards the involvement of religious leaders in politics. World Values Research 2(1):1-29. 
Norenzayan, Ara and Azim F. Shariff. 2008. The origin and evolution of religious prosociality. Science 322(5898):58-62.

Nelson, L.D. and C.H. Cantrell. 1980. Religiosity and death anxiety: A multi-dimensional analysis. Review of Religious Research 21(2):148-57

Norris, Pippa. 2004. Sacred and secular: Religion and politics worldwide. Cambridge, UK: Cambridge University Press.

Norris, Pippa and Ronald Inglehart. 2002. Islamic culture and democracy: Testing the 'clash of civilizations' thesis. Comparative Sociology 1(3-4):235-63.

Olesen, Asta. 2002. The Islamic movement in Afghanistan: National liberation and the challenge of power. In Questioning the secular state: The worldwide resurgence of religion in politics, $4^{\text {th }}$ ed., edited by David Westerlund, pp. 392-408. London, UK: C. Hurst \& Company.

Papadakis, Elim and Clive Bean. 1993. Popular support for the welfare state: A comparison between institutional regimes. Journal of Public Policy 13(3):227-54.

Pedhazur, Elazar J. 1997. Multiple regression in behavioral research: Explanation and prediction. New York: Harcourt Brace.

Pfaff, Steven and Anthony Gill. 2006. Will a million Muslims march?: Muslim interest organizations and political integration in Europe. Comparative Political Studies 39(7):803-28.

Pfau-Effinger, Birgit. 2005. Culture and welfare state policies: Reflections on a complex interrelation. Journal of Social Policy 34:3-20.

Russett, Bruce M, John R. O'Neal, and Michaelene Cox. 2000. Clash of civilizations, or realism and liberalism déjà vu? Some evidence. Journal of Peace Research 37(5):583-608.

Scott, W. Richard. 2001. Institutions and organizations: Ideas and interests. Thousand Oaks, CA: Sage.

Sherkat, Darren E. and Christopher G. Ellison. 1999. Recent developments and current controversies in the sociology of religion. Annual Review of Sociology 25(1):363-94.

Smith, Christian. 2008. Future directions in the sociology of religion. Social Forces 86(4):156189.

Stark, Rodney and William Sims Bainbridge. 1987. A theory of religion. New York: Peter Lang Publishing.

Starks, Brian and Robert V. Robinson. 2009. Two approaches to religion and politics: Moral cosmology and subcultural identity. Journal for the Scientific Study of Religion 48(4):650-69.

Svallfors, Stefan. 2003. Welfare regimes and welfare opinions: A comparison of eight Western countries. Social Indicators Research 64(3):495-520.

Tan, Jonathan H.W. and Claudia Vogel. 2008. Religion and trust: An experimental study. Journal of Economic Psychology 29(6):832-48.

Wilensky, Harold L. 1975. The welfare state and equality: Structural and ideological roots of public expenditure. Berkeley, CA: University of California Press.

World Values Survey Association. 2010. Publically available datasets. Accessed October 2010. Available at: http://www.worldvaluessurvey.org 
Yamane, David. 1997. Secularization on trial: In defense of a neosecularization paradigm. Journal for the Scientific Study of Religion 36(1):109-22. 